\title{
A LÍRAI KÖLTEMÉNYEK ÉS AZ EPOSZ VISZONYA ZRÍNYI MIK- LÓS SYRENA-KÖTETÉBEN ${ }^{1}$
}

Zrínyi Miklós, Adriai tengernek Syreneaia: groff Zrini Miklos címü, 1651-ben, Bécsben megjelent kötetében bukolikus költemények előzik meg és követik az eposzt, a gyüjteményt király- és hősepigrammák, a Feszületre címü himnusz és a Peroratio zárja. Szörényi László szerint a magyar Syrena-kötet szervezőelve a bukolikus, erotikus, elégikus költői világok küzdelme a heroikussal. A költői müfajok versengését a heroikus javára a himnusz dönti el, majd a záróvers a heroikus hangot is semmisnek nyilvánítja a valóságos hősi halál dicsőségéhez képest. Bene Sándor egy lélek történetét rekonstruálja a Syrena-kötetben, a kisebb versekböl kibontakozó morális megtisztulás-történetet pedig az eposznál fontosabbnak tartja. Mindkét értelmező az Orpheusz-versek, az epigrammák és a himnusz tájékára helyezi a kötet fordulópontját. Az Orpheusz-versekben Zrínyi Miklós első feleségét, Draskovics Mária Eusébiát siratta el. A dolgozat szerzője szerint e versek lírai énje nem fordul el a szenvedélytől, éppen ellenkezőleg, önmagát a mértéktelen szenvedéllyel határozza meg. Az Orpheuszversekben a szerelem a halál léte miatt nem ad elég biztosítékot az emberi identitás megalapozásához. A megfeszített Krisztust megszólító himnusz beszélője Isten megváltó tettében az emberi önazonosságnak mintát és formát adó cselekedetet ismeri fel. A dolgozat végkövetkeztetése szerint a kisebb verseknek az a kötetbeli funkciója, hogy az eposz által fölkínált identitásmintát egyedül hitelesként mutassák fel.

Kulcsszavak: Zrínyi Miklós, Syrena-kötet, költői müfajok versengése, morális megtisztulás-történet, Orpheusz, himnusz, identitásminta

Zrínyi Miklós Syrena-kötetének verseiről: a bukolikus szerelmi költeményekről, a király- és hősepigrammákról, az először a megfeszített Krisztushoz, majd az Atyához forduló himnuszról és a kötetet záró Peroratióról eddig három jelentős elképzelést fogalmaztak meg a kutatók. Klaniczay Tibor az erotikus verseket feltételezett keletkezésük rendjében tekintette át, és elsősorban a költővé érés dokumentumát látta bennük (Klaniczay, 1964: 60-74). A Peroratiót egyetlen bekezdésben érintette, a himnuszt pedig nem értelmezte (Klaniczay, 1964: 317). Kovács Sándor Iván monográfiájában nem csupán a költemények feltételezett

Utasi Csilla, csilla.utasi@gmail.com 
időrendjét rekonstruálta, hanem a verseket az életesemények, olvasmányok, irodalmi hatások szövevényeként felfogott életrajzi narratívában helyezte el. (Kovács, 1985: 44-73).

Szörényi László úgy véli, a magyar Syrena-kötet szervezőelve:

(...) a bukolikus, erotikus, elégikus költői világ tematikájának küzdelme a heroikussal: költői tárgykörök versengése, ezt pedig a heroikus javára az a himnusz dönti el, amely visszamenőleg felülmúlhatatlanul magasztosabb, mert biblikusan alátámasztott megváltás-történetnek minősíti a heroikus hangot, azaz az eposzt, amelyen belül mint enciklopédikus világon belül már amúgy is elnyerte etikailag minősíthető helyét a boldog és boldogtalan szerelem. A Peroratio ehhez képest vállalja a vegyes tematika súlyozott megalkotásából fakadó költői dicsőséget, de csak azért, hogy magát az egész irodalmi teljesítményt súlytalanná nyilvánítsa a mártírium elnyeréséért folytatott harc nem irodalmi dicsőségéhez képest. Vagyis nem csupán az eposzhős Zrínyit nyilvánítsa ezzel Krisztus követőjének, hanem önmagát, a költőt. (Szörényi, 2004: 307)²

Míg a megelőző értelmezések az eposznak juttatták a központi szerepet, Bene Sándor szerint a kisebb költeményekben egy lélek története, egy neosztoikus ihletésủ morálfilozófiai megtisztulás-történet bontakozik ki, melyben a föhös az érzéki szenvedélyektől megtisztulva méltóvá válik örökbe kapott nevéhez és életfeladatához (Bene, 2014b).

\section{A tett és a költői mü párhuzama}

Zrínyi Miklós a Syrena-kötet Az olvasónak címü ajánlásának első mondatában a maga munkáját Homérosz eposzírásával állítja párhuzamba: Homérosz száz esztendővel a trójai veszedelem után írta históriáját, s ö is száz évvel az ostrom után írta meg a Szigeti veszedelmet. A második mondatban a különbözésre kerül a hangsúly: Vergilius több mint kilenc évig írta az Aeneist, ő pedig egy esztendőben, sőt egy télben vitte véghez munkáját. Ezekhez hozzáteszi: „Eggyikhezis nem hasomlitom pennámat; de aval ő elöttök kérkedhetem, hogy az én professiom avagy mesterségem nem az Poësis, hanem nagyobb, s' jobb országunk szolgálattiára annál: az kit irtam, mulatságért irtam, semmi jutalmot nem varok erette."

Király Erzsébet szerint a szerző a fönti mondatokban az ars tekintetében nem méri magát az ősökhöz, a régi költőkkel szembeni fölénye, a poéziséből hiányzó aemulatio „az ország szolgálatjában” nyilvánul meg. Zrínyi esetében „nem profi mivolta” olyannyira a „poesis”-t meghatározó elemmé válik, hogy:

E ponton fel is kell adnunk poétika, ideológia és személyesség elkülönítését, amely nélkülözhetetlen módszerbeli eljárás akkor, amikor a poétikai mủveltség tartalmát és forrásait igyekszünk azonosítani, de abszurd, mikor a költői személyiséget érintő kérdésről van szó; ennek a személyiségnek az esetében

A kötetkompozíció kérdéséről lásd még, Szörényi, 2007: 467-486. 
különösen az, mert az etikai és politikai elkötelezettség a poézisban immanens módon van jelen. (Király, 1989: 79)

A szerző etikai és politikai elkötelezettsége a költői müben akkor volna immanens módon jelen, ha a költői hivatástól különböző, a fönemesi helyzethez méltó, az államférfiúi, hadvezéri professiót azonosíthatnánk azzal a tettel, amelyet a szerző valamennyi elméleti megnyilatkozásában párhuzamba állít elvégzett költői munkával. Elsőként a dedikációban: ,,Dedicálom ezt az munkámat magyar nemességnek, adja Isten, hogy véremet utolsó csöppig hasznossan néki dedicálhassam: áldozhassam” A vér utolsó csöppig való feláldozása az Obsidio két számozatlan versszakában megismétlődik. A Szigetvárra zúduló pokoli sereg éjszakai támadását leíró Pars decima quartát Demirhám és Deli Vid utolsó, mindkettejük halálával végződő párviadala zárja. Az utolsó strófában az ég „,sok szemmel”, csillagaival tanúja a hős halálának:

Légy bizonsága ég, Deli Vid végének

Mert sok szemmel nézted utolliát éltének

Egy chöppig ki atta vérét Istenének

Légy tudománi tevö Deli Vid végének.

(Szv XIV. utolsó, számozatlan versszak).

Az Obsidio utolsó versszakában a hősi halál a név vérrel való aláírását, a teljes lény odaajánlását, dedikációját jelenti, ahogyan erre már Kovács Sándor is felhívta a figyelmet (Kovács, 1980: 16):

Vitézek Istene! ime az te szolgád

Nem szánta éretted világi romlását;

Vére hullásával nagy bötüket formált,

Illy subscribálással néked adta magát,

Ö vitéz véréért vedd kedvedben fiát!

(Szv. XV. utolsó, számozatlan versszak)

Az eposz legfontosabb hőseinek halálát leíró, az eredeti müben is dőlt betűkkel kiemelt versszakok távlatából úgy tünik, Zrínyi Miklós a dedikációban a magyar nemesség szolgálata helyett azt kéri, vérét utolsó cseppig Istennek áldozhassa. A mártírhalál ebben az összefüggésben több a világban betöltött professiónál, a tökéletesen, végérvényesen megformált emberi önazonosságot jelenti. A kötet szerzője úgy válik méltóvá őséhez, hogy követi tettét: a dedikációban a megismétlés vágya fejeződik ki.

\section{A vitéz és a szirének}

A címlapmetszetnek, Juraj Šubarić munkájának előképét Klaniczay Tibor azonosította, allegorikus jelentését az utóbbi évtizedekben kezdték kihüvelyezni. 
Bene Sándor a kép elemeit erőteljesen bevonta a kötetszerkezet jelentésének értelmezésébe (Bene, 2015a: 50)

Vittorio Siri történeti munkájának ábrázolásán a mellvértet, combközépig érő tunikát és szárnyas sarut, fején szárnyas kalapot viselő Mercurius egyik kezében szárnyas botját tartja, másik kezében pedig egy stafétabotra emlékeztető henger alakú tárgyat tart - talán az üzenetet tartalmazó írástekercset, amelyet rá bíztak. A hírnök-isten elé meztelen nőalak, a nuda Veritas tart tükröt. Az isten arcát profilból látjuk, felsőtestét azonban féloldalról. A magyar címlapmetszet vitézének testét páncél borítja, ahhoz hasonlóan, ahogy a kora újkori síremlékeken viselnek páncélt az elhunytak, mellén keresztben széles szalag. Nem a halál pózában fekszik, merőn maga elé tekint. Arcát a kora-reneszánsz arcképek beállításában, profilból látjuk. A korai reneszánsz portrékon az arcél megjelenítése az ábrázoltak tekintélyét, örök hírét jelöli. ${ }^{3}$ A metszeten a vitéz is, Mercuriusához hasonlóan, henger alakú tárgyat fog a kezében. A metszet átvitt értelme szempontjából szinte egyre megy, hogy a hengerben a mủ szövegét rejtő írástekercset, vagy pennavalist, vagy a vitézségre utaló hadvezéri pálcát látunk-e.

Kiss Farkas Gábor a magyar Syrena-kötet címlapmetszetében az embléma struktúráját azonosította. A vitéz hajójának árbóca köré tekeredő szalagon olvasható latin mottót, Zrínyi Miklós jelmondatát feleltette meg a subscriptiónak, és megfigyelte, az ábrázolásból hiányzik az inscriptiót és a picturát egymásra vonatkoztató elem, az epigramma; a subscriptio hiánya azonban nem számított a korban szokatlannak (Kiss Farkas, 2006: 89). A kagylót nyújtó, halfarkat és csípőjén pamacsszerü, csökevényes szárnyat viselő nőalak valószínűleg a bujaságot, a hasonló testü, tükörben fésülködő szirén pedig a hiúságot jelenti.

Német tudósok csoportja korábbi felismeréseket és a foucault-i tudásarcheológia eredményeit kamatoztatva a kora újkor megkülönböztető jegyének az igazság megsokszorozódását tartja ${ }^{4}$. David Nelting a bukolikus költészet szempontjából emeli ki annak fontosságát, hogy az ókori és középkori retorikában a narráció egyik válfajaként meghatározott, ám ekkor már múfajnévként is használt fabula a kora újkorban igazságot is kifejezhetett. A középkori írásmagyarázat a sensus spiritualist a Szentírás számára tartotta fenn, az irodalom mint integumentum átvitt jelentését pedig a morális értelemre korlátozta. A kora újkor kezdetén a Szentíráson kívül lelki értelmet kezdtek tulajdonítani az emberi alkotású irodalmi műveknek is, az elsők között Petrarca (Nelting, 2007: 28-29).

A kora újkort a pluralizációs irányzatok mellett a tekintély is változatlanul alakította, a korabeli episztémét tehát a szétszóródást segítő erő, a pluralizáció, s

Saša Brajović az európa portréról és önarcképről írt könyvében rámutat arra, hogy az itáliai arcképfestészetben a 15. században népszerü, a modellt profilból ábrázoló portré a személyes jelleget nem ragadja meg, hiszen az az asszimetrián, a két arcfél különbözésén alapul. A profilkép, ez az antik kámeák és érmék mintáját követő szimbolikus forma a személyt a közösségi tekintély letéteményeseként helyezi a nyílt politikai térbe. (Brajović, 2009: 45-46).

4 Amüncheni Ludwigs-Maximilian-Universitäten működö, Pluralisierung und Autorität in der Frühen Neuzeit címü projektum kutatói: Jan-Dirk Müller, Wulf Oesterreicher, Gerhard Regn, Winfried Schulze és mások. A pluralizáció és autoritás fogalmához lásd még: Müller, Oesterreicher, Vollhard (szerk.), 2010. 
egy ellentétes irányba ható, összefogó erő, a tekintély határozta meg. A korszakra jellemző ismeretelméleti együttállás nyomot hagyott a korabeli müvek szerkezetén is: struktúrájukat rendre egyféle agonális dinamika jellemzi. Az autoritásnak a művekben kialakított változata, noha hatósugara eltérö terjedelmü lehet, sohasem feltétlen érvényü és kétségbevonhatatlan. (Nelting, 2007: 9-14)

Az embléma maga is minden bizonnyal a pluralizációs folyamatoknak és a fabula értéknövekedésének terméke. Érvényes igazságok felismerését és megjegyzését segítette elö, a mnemotechnika eszköze volt.

A Syrena-kötet címlapmetszetén nem csupán a subscriptio hiányzik, az sem világos, mit tekintsünk inscriptiónak, hiszen a könyv címe éppen úgy szolgálhat feliratul, mint Zrínyi Miklós jelmondata. A többszörösen csonka embléma subscriptióját, az epigrammát a kötet teljes szövege helyettesíti. Az Obsidio kilencedik éneke (Szv IX. 3: 1) az eposzírást nevezi hajózásnak, a Pars decima quartá-t pedig következő kép vezeti be:

Ihon jün Zrininek ragyago csillaga, Ihon mozdulhatatlan tramontanáia

Ban chelekedet az én kezem iria, Mellyet Isten lölke elmémben be-fuia.

Nem távozik annak veszélyre haiója,

Melynek ez chilaghoz tart okos kormánia, Hüvség, vitézség ennek calamitaia, Az mely ez chillagot veszteni nem hagya.

Már én mágnes küvem portushoz hoz engen,

Szerencséssen jüttem altal ez tengeren,

Immár barátimat az parton esmerem,

Mellyek nagy örömmel jüttek én előmben.

(Szv XI. 1-3)

A hajónt az eposz éneklésének jelen időbe átváltó, fabulaszerűen megjelenített valóságsíkja. Az örök hírnevet biztosító mü kiadatása pillanatában ugyan már elkészült, a metszet azonban nem a kikötőbe befutott, hanem az úton levő hajót ábrázolja, hiszen az emblematika a kikötőbe érkező hajóhoz más jelentéseket társít. $^{5}$

Az eposz története a szigeti várkapitány tettének leírásához közeledik, a narráció jelenét ábrázoló tengeren az elbeszélő egy metaforára mutat rá. A „Zrini ragyago csillaga”, „mozdulhatatlan tramontanáia” a család, a nemzetség vezérlő csillaga, a dédapa mártírhalálát kifejező metafora. A bán cselekedetének leírását a Szentlélek sugallja, ami egyfelől azt jelenti, hogy a tett méltó leírására a szerző

Lásd Henkel, Schöne, 1996. A hajót különböző helyzetekben ábrázoló emblémák a kötetben: 1453-1470. 
emberi tehetsége nem elég, másfelől azt, hogy a hősi tettet a túlvilág igazolja. A tramontana, a Sarkcsillag, az északi féltekén a helyét legkevésbé változtató égitest olasz neve. A nyílt tengeren, ahol az északi irányhoz ezen kívül semmilyen más objektum nem rendelhető, a hajósok a Sarkcsillag segítségével tájékozódnak. A család férfitagjai, a szigeti hős utódai számára az ős mártírhalála az orientációs pont. A földrajzi és hajózási metaforákból felépülő concetto a csillag utáni tájékozódást segítő eszközt is metaforikusan nevezi meg: a kormányosnak a hívség és a vitézség a calamitája, azaz az iránytüje.

A fönt elemzett részlet az Obsidio talán leghosszabb szerzői kommentárja. A továbbiakban azt szeretném kifejteni, hogy a kisebb versek az emberi identitás megszerzését a fönti kitérőhöz hasonlóan nem történetként, hanem a jelenben bekövetkező választásként tételezik.

\section{A versek küzdö jellege}

Az epigrammák, a Feszületre és a Peroratio kivételével a kötet valamennyi verse pásztori költemény. A bukolikus világ hőseiben és a közöttük megképződő viszonyokban a horvátországi arisztokrata családok alakjaira ismerhetünk, a pásztori világ hősei azonban nem életbeli szerepeiket játsszák. A Balassi-kutatás a Szép magyar komédia cselekményét sokáig Balassi Bálint valós élettényeit allegorikusan megjelenítő történetnek tartotta, Köszeghy Péter meggyőzően bizonyította be a fikció fölényét az életrajzzal szemben. Balassi a Julia-ciklus megírásával körülbelül egyidőben fordította le Cristoforo Casteletti pásztorjátékát. Mindkét müvet, a Julia-ciklus is, és a Szép magyar komédia is Losonczy Anna megnyerésére szolgált. A pásztorjáték bizonyos tekintetben (ál)kulcsdráma: „Olyan, mintha megtörtént szerelmi eseményt mesélne el a két kulcsfigura, Credulus és Julia segítségével. Valójában álkulcsfigurák ők, hiszen a dráma fikciós történetéről akarják elhitetni, hogy az életben, a Balassi Bálint és Losonczy Anna között is imigyen történt" (Kőszeghy 2014: 377-378)

David Nelting megállapítja, hogy ,a bukolika fikciós tere nem allegorikus reprezentációként rendelődik az életvilág fölé, hanem a gyakran a világelsajátítás retorikájába torkolló beszéd- és cselekvésmodelleket próbál ki." (Nelting, 2007: 7). A pásztori fikció terei a szerelem- és a hatalom elméleteit, az udvari magatartást, poétikai modelleket és magát az egymásnak feszülő álláspontok alakját öltő kora újkori episztémé kérdéseit jelenítik meg. A bukolika fikciós térsége olyan színpadként müködik, melyen a különböző tekintélyek játékosan kétségbe vonódnak, s egymás ellen kijátszódnak. (Nelting, 2007: 7).

A kora újkori bukolika alakulástörténetét felvázoló németországi kutatás Marino pásztori költészetét az itáliai pásztori irodalom végpontjára helyezi, és egészen autopoétikusnak látja: Marino müvében radikálisan önreflexív gesztusként felszámolódik a bukolikus költészet modelláló jellege (Nelting, 2007: 227-259). A Syrena-kötetben az eposz mimézisz-elvü elbeszélésével szemben a lírai 
költemények nem utalnak valóságra. Zrínyit mintha a költészetnek mint tiszta reprezentációnak a kérdése foglalkoztatná, verseinek ez a jegye azonban nem vezethető vissza közvetlenül Marino imitációjára.

Az első Idilium elbeszélő keretettel indul: a főhős, a megbúsult vadász, miután hiába járta a Dráva erdejét, Cupidóval találkozik, aki biztosítja őt hatalmáról, nyila mindenütt ölni és fojtani fogja, bárhova menekülne előle. A szóváltás után a vadász egy kidőlt fára telepedve előadja énekét. A távollevő Violához szól, körülötte, mint mondja, „vigaszik minden, a kikeleti nép“, rájuk hivatkozva panaszolja föl Violának hajthatatlanságát. A 17. versszakban azt is megállapítja: „Heában tégedet apolgatny verssel” (Idilium I: 17: 3); a női szépség mulandóságára és a gyönyör időben való élvezetére figyelmeztető sorok után pedig a mindenen uralkodó szerelem hatalmával érvel, majd Violát kegyetlenséggel vádolja, felteszi, hogy Viola nem hisz esküvéseinek, újabb, be nem tartásuk esetén szörnyü büntetést maguk után vonó esküket tesz, végül rádöbben szerelme reménytelenségére: Viola a vele szemben mindenben alulmaradó Licaont szereti. A monológ Viola kérlélésével, a kilátásba helyezett ajándékok felsorolásával, majd a reménytelenség újbóli belátásával zárul. Az ének elhangzását követően az idill elsődleges elbeszélője Violát jelenvalóként szólítja meg: „Kit gyülölsz Viola keduedben lészen az" (Idilum I. 71:4). Viola utolsó aposztrophéját az elbeszélő teljhatalmaként kell értenünk akkor is, ha azt tételezzük fel, a vadásztól távol levő Violához valóságosan képes szólni, akkor is, ha szavait jóslatként fogjuk fel. Mind az első, mind pedig a második Idiliumban, melyben a vadász Violát üldözi, a szerelmes és a szeretett nő külső és belső jegyei erőteljesen bukolikus színezetüek. Egy-egy villanásra Viola és a vadász szinte a pásztori világ bárdolatlan, zabolátlan szereplöire hasonlít, példa erre Viola vadsága (Idilium I. 13, 15, 49, 50) és a Violának szánt, kicsit suta ajándékok sora (Idilium I. 63-67).

Bene Sándor szerint Zrínyi a kötet szerkezetében fiktív időrendet teremtett meg: „A Syrena-kötet egyik legfontosabb narratív szála maga a kötet írása, a kronológia (a fiktív kronológia!) tematizálása" (Bene, 2015a: 46). Úgy látom, az elöre- és hátrautalásokból nem bontakozik ki történet, bennük egy-egy pillanatra az adott müfajra jellemző mimézisz síkja törik meg, a szövegekbe iktatott új fikciósík távlatából pedig az eposz és a versek diszkurzusjellege lepleződik le. A hősköltemény elbeszélője a propositio előtt játékként határozza meg korábbi erotikus verseit: „Én az ki az előt iffju elmével / Iátcottam szerelemnek édes versével / küszködtem viola kegyetlenségével: / immár Mársnak hangassabb verséuel, // Fegyvert, s Vitézt éneklek, Török hatalmát, / Ki meg merte várny Szuliman haragiát / Ama nagy Szulimánnal hatalmas karját, / Az kinek Europa rettegte szablyáiát." (Szv I. 1) A játék a tudatos imitáció szándékát jelzi, a bukolikus tér megalkotását. Ugyanez az elbeszélő olykor a mimézis illúzióját leromboló személyes kijelentéseket tesz ( $S z v$. IV. 8., 9-11., XIV. 1-12.), amivel az eposz elbeszélt mivoltát, diszkurzusjellegét emeli ki.

Az Ariánna sírását nagy erejü kérdések vezetik be: „Adria tengernek fön forgo habjai / Vallyon oly nagyoké mint szemem árjai, / Vallyon oly nagyoké Mongybél 
lángjai? / Mint égő szüvemnek langos hatalmai." (Ariánna sírása. 1). A Syrenakötetnek petrarkista toposzokat használó verseiben a szerelemre mint világformáló erőre reflektáló, önmagát a szerelemről való beszéddel meghatározó Én nem alakul meg. Zrínyi az idézett kérdésekben megfordítja a hasonlónak és a hasonlítottnak a petrarkista képekben szokásos rendjét. Nem azt állapítja meg, hogy szeme árjai oly nagyok, mint az Adriai tengernek fönnforgó habjai, égő szüvének lángos hatalmai pedig oly nagyok, mint a Mongybél lángjai. Nem a szenvedélye nagyságát érzékelteti a természeti jelenségek segítségével, hanem fordítva, a felmérhetetlen, nagyságukban mégis véges természeti jelenségeket azért vonultatja fel az olvasó szeme elött, hogy saját szenvedélyét a láthatónál, az elképzelhetőnél nagyobbnak: mérhetetlennek állítsa. Az eposzt megidéző sorok („Én Márst énekelek haragos fegyverrel, / Kinzo szerelmemet hogy feleitsem evel, / Más felöl kis Isten meg kerül fegyverrel, / Hartzol, vagdalkozik lángozo szüvemmel”, Ariánna sírása. 4) vívási jelenete körmönfontan aláássa a petrarkista líra alaphelyzetét. A kis isten a támadással arra sarkallja a beszélőt, hogy hitelesebben fejezze ki szerelmét: annak fejében kíméli meg életét, ha Viola kegyetlensége helyett Ariánna sírását énekli meg. Voltaképpen azt követeli, petrarkista panasz helyett egy szerepverset írjon. Cupido parancsa természetesen a szerző fiktív, a monológ beiktatását megindokló érve, az argumentummal azonban a petrarkista költészet paneleivel játszó azt is jelzi, hogy a szerelem és a róla való beszéd nem Cupido, hanem az ő hatalmában van. Mielött a Cupidótól kapott feladatot teljesítené, Violát aposztrofálva elpanaszolja szenvedéseit és hiába való utána járását. Mint mondja, azt írná meg szívesen, mennyi sok ohajtást érette sürü fölyhők közé szélnek bocsátott, mennyiszer könyvével ezt az sebes Drávát árasztotta s nevelte haragos árját, és figyelmezteti Violát, hogy a versnek magára vegye értelmét (Ariánna sírása $6-7,10)^{6}$. Ariánna magánbeszédének végén a heroidaformára jellemző mimézisz csorbát szenved, a hősnő arcán áttünnek az elsődleges beszélő, a szerelmes férfi vonásai: „Sem siet, sem késik haragia Istennek, / Mert örvényes habbá teheti könyvemet / Szélvésszé fordittya sohaito kedvemet / En bánatimmal el-buritnak tégedet." (Ariánna sírása. 37). A heroida-müfaj utánzásjellegének lelepleződésével a természeti erővé átváltozott szenvedély kikerül a reflexív énformálás kényszeréből.

A következö, cím nélküli költeményben ${ }^{7}$ az immár Titirus, a hagyományosan Vergiliusszal azonosított pásztor nevét viselő szerelmes és a pásztorlánnyá nemesedett Viola egymásra találnak. A szerelmesek megbékélését Zrínyi nem is jeleníthette volna meg másként, mint pásztori környezetben: a petrarkista líra a kölcsönösséget szinte kizárja. A párbeszédes költemény „,cselekménye” a pásztori

Az első Idilium vadásza önmagát a következőkre szólítja fel: „Neveld az vizeket könyv-hullatásiddal / Sürösich fölyhőket sok sohajtásiddal” (Idilium I. 69: 3-4). Az első Orpheus vers lírai énje többek a Drávát így kéri: „Siry teis gyors Dráva erős bizonságom / Ki voltál égő szüvemnek orvosságom/ Téged sokszor meg-nevelt én könnyhullásom / Sokszor te oltottad az én gyulat lángom" (Orpheusz I. 14).

7 A kötet két címtelen költeménye közül az elsőre a versnek a szinte a teljes Syrena-kötetet tartalmazó zágrábi kéziratban, az ún. Syrena-kódexben megadott címmel (Fantasia poetica) hivatkozom, a másodikra azon a címen, melyet Kazinczy adott a költeménynek ( $A$ vadász és Echo). 
irodalom közhelyeiből épül fel. Viola hűtlenséggel vádolja Titirust, aki hűségét bizonygatja és felpanaszolja Violának, hogy Licaon, a vetélytárs költészetét az övénél többre becsüli. A párbeszéd végén kiderül, Viola azért bujdosott el a pásztori világból, mert Licaon meggyanúsította, Titirusnak köt kerékbe eperjet ${ }^{8}$, és a kosarat durván kiverte kezéből. A bukolikát egyetlen korban sem tekinthetjük egységes müfajnak, már Theokritosz pásztori költeményeit is a hagyománytól való tudatos elhatárolódás, a hagyományra való játékos-destruktív rájátszások, a müfajok keveredése jellemezte (Nelting, 2007: 44). Titirus és Licaon verseiket nem adják elő, a közöttük folyó képletes költői versenynek tehát bizonyosan nem az a célja, hogy benne müfajok, stílusnemek mérkőzzenek meg. Viola Titirus szerelmének viszonzását mindvégig a pásztor költészete értésével, értékelésével hozza összefüggésbe. Utolsó, Tassót idéző szavaiban is erre utal: „Ugy légyen édes szüvem, az mint akarod, / Mert engemet az te szép versed meg-hajtot / Immáron ez után lészek te szolgálod, / Társod és szeretőd és te szép virágod." (Fantasia poetica. 24). Zrínyi versének szereplői a szerelmet kiegyenlítik a költészettel: a létrehozott bukolikus világ nem utal semmilyen külső valóságra, önmagát jeleníti meg. Viola szavai nyomán a versbe foglalt vágy a boldogság ígéretévé válik.

A kötet utolsó erotikus költeménye a petrarkista és a pásztori hagyomány metszéspontján helyezkedik el. A müfajszabályok szerint a versén Echo nimfát kérdezgeti, szerelmével kapcsolatos bizonytalan kérdésekben kér tőle útmutatást. A nimfa a kérdés utolsó szótagjait némileg eltorzító, értelmes rímekben felel, kétértelmü és csúfondáros válaszokat ad, amelyek felépítik és egyúttal le is rombolják a szerelmes versén önazonosságát. Bene Sándor két érvvel bizonyítja, hogy a vers a Balassi költészetével való versengés jegyében keletkezett. Elöször azt állapítja meg, hogy a Julia név Balassi költészetéből származik, és Viola rejtózik mögötte (Bene 2015c: 57). Másodszor Zrínyi merészen erotikus képeire hívja fel a figyelmet: „A paródia forrása megintcsak Balassi maga, a 24., Most adá virágom nekem bokrétáját... kezdetủ vers — amely a hagyományos 'nő/viráge metaforikát fejti ki. Teljesen természetes hát, hogy az eleve virágként jelölt hölgy, ha csokrot ad, »magához hasonló szerelmes virágát« nyújtja a férfinak. Zrínyinél ez már-már értelmezhetetlenül trágár képbe fordul: a fallikus jelképpé alakult rózsa önmagát hasonlítja a méhecskéhez, vagyis az imádott nőhöz: »Maga szép illatos, / Hozzád hasomlatos.« (Fantasia poetica II. 9: 32-33). Ehhez képest még az is szelíd humornak számít, amikor a hölgyet arra biztatja: »Csak te jüjj és szállj rá, / Kívánod másszorra / Ỏ állandóságát, Ronthatatlanságát.« (9: 36-39). Az »állandóság « itt természetesen teljesen mást jelent, mint Balassinál (»Virágja mind elhull, csak a töve marad, / Légy állandó hozzám végig, mint én tehozzád «)" (Bene, 2014c: 58.) A rózsa a költemény végére metonimiává egyértelmüsödik: „pars pro toto: a férfi »rózsája«" (Bene, 2014c: 58).

\footnotetext{
A kosárka eperj szerepel Balassi Bálint Szép magyar komédiájában is (act.III.sc 4). Erről és a vers további, a Szép magyar komédiára utaló helyeiről lásd: Bene, 2014c: 57.
} 
Ricoeur az Énekek Énekéről írja az alábbiakat, ám amit állít, maradéktalanul illik Zrínyi rózsa-metaforájára is: „A fontos [...] nem az az eufemizmus, mely megörzi a szexuális referenst annak közvetlen megnevezése nélkül; az a fontos, hogy maga a test is beléfoglaltatik a költemény átfogó metaforikus játékába [...]" (Ricoeur, Lacocque 2003: 532). LaCocque értelmezésével szemben, aki Sulamitban látja a vers szerzőjét és felforgató költeményként olvassa, amely a testi szerelmet bibliai fogalmak parodizáló használatával dicsőíti, Ricouer hermeneutikai módszerrel mutatja meg azt, hogy az allegorikus olvasat eredendően benne foglaltatik a szövegben. Az Énekek Éneke egyetlen pontján sem szól a beteljesülésről. „A testi szerelem talán az 5,1-ben vagy a 6,3-ban teljesül; ám ezt nem mondja ki a leírás csak az ének utal rá. Ezért kérdezhetjük, hogy a valóságos beteljesülés nem magában az énekben történik-e? S ha mint föntebb javasoltuk, a valóságos kifejlet a 8,6-ban történik meg? »Tégy engem mintegy pecsétet a te szívedre, / mintegy pecsétet a te karodra«, úgy nem a soha le nem írt, soha el nem mesélt beteljesülés a fontos, hanem a szövetségi fogadalom - ezt jelenti a pecsét -, mely a nász lelke, melynek teste a megénekelt fizikai beteljesülés volna. Amikor azonban a nász az érzékibe ágyazódik, a test lélek, és a lélek test." (Ricoeur, LaCocque 2003: 529-530). Zrínyi versében, melyben a kérdezkedést két nótabetét szakítja meg, az elsőt, a múltbeli történetet a beszélő a nimfa vigasztalására mondja el, a másikat pedig szerelmesének küldi üzenetként. A beszélő kertjében időző méhecske, gyönyörüségecskéje, akin „megnyugodott volt” szüve, s aki őt táplálta, „csak láttatjával is” (A vadász és Echo. 3: 3, 8), a női szereplö, a versén szerelmese. A merészen erotikus képek, melyekben a férfi Hercules oszlopaiként nevezi meg a méhecske két szép lábát, és azt kívánja, bárcsak dőlne rá szép márvány palotája, ahogy rádőlt Sámsonra, a beteljesülés vágyát írják le. A fordulatot az hozza, hogy a méh a kerttől és a benne álló rózsától a nádhoz pártol át. A két nótát összekötő párbeszédben Echo egyrészt csúfondárosan azt feleli a kérdezőnek, nem kell meghalnia bánatában, másrészt hajlandóságot mutat a méhecskének szóló üzenet átadására. A beszélő a nimfa szájába adott néhány megfelelő válasz után („,Ha kérdi éleké, mongyad hogy én égek, / Ha kérdi kichoda, mongyad hogy van oda” 8:5) szerelmeséhez fordulva megnevezi magát. „Az te rózsavirágod" (8:6). A versben Zrínyi Balassi költészetét ironikusan kezeli, ám ez az irónia nem a drasztikus erotika megteremtését célozza. A rózsa (a lírai én), ugyanis nem metonímia, hanem metafora. A kölcsönösséget vagy a kölcsönösség vágyát a felszólító mód jelzi. A vallomás és rábeszélés jelen idejü, ebben sem a rózsa gyökerének ,erőssége”, sem az álhatatottsága nem nyernek még bizonyítást, és a méhecske tetszése is a kérlelő rábeszélésben van csak jelen. Az Énekek Énekéhez hasonlóan a szerelem, a petrakista női és férfi szerepeket ellentétükbe fordító mozgásokban és a vallomás jelen idejében teljesül be, és eközben: „maga a test is beléfoglaltatik a költemény átfogó metaforikus játékába”, ,a költemény a beteljesülést a középpontba és nem a végére helyezi, ami lehetővé teszi, hogy közeledtét [...] az elbeszélő jelen ürességében idézze fel, melyet csak az ének tölt be" (Ricoeur, La Cocque 2003:532, 530) 


\section{Orpheusz álarca}

A kötet fordulópontját mind Szörényi László, mind pedig Bene Sándor az Orpheusz-versek tájékán jelölte ki. Az erotikus és a hősies költészet küzdelme itt érkezik el döntő szakaszához. A morális megtisztulásfolyamat kezdete ez: a bűnben és kárhozatban való egyesülés után „Orpheusz alakjában az elbeszélő gyönyörvágyó énje is meghal” (Bene, 2014a: 49).

Orpheusz a mitológiai szereplők közül nem erejével vagy leleményességével, hanem szerelmének nagyságával és mágikus költői hatalmával tűnt ki. A korai újkori befogadók a történetét morális példaként értelmezték. A fönemesi-uralkodói önábrázolás és politikai propaganda meghökkentő csonkításokat hajtott végre mítoszán ${ }^{9}$. Az állatokat megszelídítő muzsikája ereje tette alakját a jó királyi hatalom allegóriájává, határtalan szerelme pedig esküvői élőképek kedvelt alakjává.

A trák énekesnek a középkorban is ismert történetét 1480 táján Angelo Poliziano helyezte elöször pásztori környezetbe Fabula di Orfeo címü játékában. A mü eredetileg Francesco Gonzaga bíboros „banchetto spectacolo”-ként jellemzett ünnepségére készült (Nelting, 2007: 83). Poliziano kerettörténetbe illeszti a mítoszt. Egy Mopso nevü öreg pásztor beszélget ifjabb, Aristeo nevü társával. Calpurnius harmadik eklogáját megidézve a szerelemről folyik a szó, majd Aristeo pásztorsípján, az árnyas lombok alatt éneket ad elő (többek között Theokritosz Küklopszának panaszát is megidézve). A kettőshöz csatlakozik egy harmadik pásztor, Tyrsi, s egy csodálatos szépségü nimfáról mesél. Aristeo Euridicére ismer a nimfában, üldözni kezdi öt, a menekülö Euridicét pedig halálosan megmarja egy kígyó. Ismeretlen pásztor viszi meg Euridice halálhírét férjének, Orpheusznak, aki fölhangzó panaszával engedélyt kap arra, hogy feleségét az alvilágból felhozza, ám újra elveszíti őt. Ekkor megfogadja, ezután a fiúszerelem felé fordul, s a bakkhánsnők széttépik (Poliziano 2003)

Zrínyi három hangsúlyos változtatást hajt végre a mítosz szövegén. A történeten elöször a párvers első darabjának argumentumában (Orfeus az szép Euridice után futván, Euridicét egy vipera megcsípte, az mely mérges sebben megholt Euridice) módosít, hiszen a mítosszal szemben Euridice véletlen halálát Orpheusznak tulajdonítja ${ }^{10}$.

9 1585-ben, Düsseldorfban Johann Wilhelm Jülich, Kleve és Berg hercege feleségül vette Jacobe von Baden örgrófnőt, a menyegző harmadik napján, egy jelmezes versenyfutás elöjátékában forgó hegyet vontattak be, egyik oldalán a muzsikájával köveket mozdító, a családi harmóniát megjelenítő Amphión, a másik oldalán Orpheusz volt látható, énekétől megszelídült vadállatok társaságában Beschreibung derer Fürstlich Güligschen Hochzeit so Anno 1585 zu Düsseldorfi mit grossen Freuden, Fürstlichem Triumph und Herrlichkeit gehalten worden, Cölln 1587 (A leírást ismerteti és a metszetet közli Krems, 2009: 269) 1571-ben, I. Ferdinánd császár legfiatalabb fiának, Károly főhercegnek és Bajor Máriának a menyegzőjén előadott élőképen az Aetnaként ábrázolt alvilágban Orpheusz és Eurüdiké boldog együttértésben ültek egymás mellett. Az esküvő alkalmához nem illett a szerelmesek elválásának megjelenítése. A mítosz vége más főúri menyegzők élőképeiből is hiányzik (Krems, 2009: 271-273)

10 A Draskovics család tagjai terjesztették el a hírt, hogy Draskovics Mária Eusébia halálát mérgezés okozta. Bene Sándor a Zrínyi és Draskovics család között dúló, még a 16. századra visszamenő viszály és a házassággal előállt bonyolult birtokviszonyok felderítésével meggyőzően bizonyítja, hogy Zrínyi Miklósnak nem állt érdekében felesége halála (Bene, 2015: 42-43). Az argumentum mítoszkorrekcióját 
Az eredeti történet szerint Orpheusz abban a pillanatban veszíti el világot harmonizáló képességét, amikor Eurüdikére hátrapillant. A fordulatot a korszak festményei gyakran úgy ábrázolják, hogy lantja vagy violája kiesik a kezéből (Krems 2009: 287-288) ${ }^{11}$. Noha a párvers első darabja az alvilágba való leszállás előtt hangzik fel, Zrínyi Orpheusza ekkor már nincs költői hatalmának birtokában. A dispositio különös feszültsége szervezi a verset, mint Zrínyi esetében legtöbbször. A felütésben a beszélő a gyász méltó reakcióit mitológiai szereplőktől kéri a maga számára. Apollótól, aki a költészet mesterségére tanította, és aki talán apja is, azt kéri, torkát nyissa meg keserves sírásra, Biblistől azt, hogy két szeme forrását nyissa meg, Echótól, hogy sürüsítse meg lölke sohajtását. A mitológiai hősök nem a beszélő teste fölötti uralmat, hanem a versszöveg, a költemény diszkurzusának „teste” fölötti uralmat nyerik el, így pótolják a költői képesség elvesztésével beállt hiányt, melyet maguk az aposztrophék létesítettek. A harmadik versszakban Eurüdiké múlt idejü jellemzésével megadja gyásza okát, az Eurüdikét leíró virágés a csillagmetafora később megismétlődik a költeményben.

A versén önmaga állapotát kétféleképpen jelöli meg. Amint ezt a költők a Platónnak tulajdonított epigramma óta sokszor tették, kifejti, lelke nincs a testében ${ }^{12}$, hanem kedvesénél tartózkodik. A teste úgy él ezen a veszett világon, hogy nincs benne az éltető lélek, nem is élő immár, hanem „mély pokolból jütt vándorló lélek" (Orpheusz I. 9: 4). A kijelentést, mely szerint nem Orfeus többé, úgy kell értenünk, hogy a lelke tette azzá. A Hádészban névtelen árnyak bolyongnak. Test és lélek ilyen felcserélésével szabad a poklokra alászállnia. Eurüdiké szólongató fölidézése a beszélö másik állapotrajzának megfogalmazásához vezet át. Megidéződik Eurüdiké alakja, rá emlékezve a szerelem Paradicsomnak tetszik, a nélküle való élet pedig Pokolnak (Orpheusz I. 21-24). ${ }^{13}$ Ezen a helyen Zrínyi ismét a petrarkista költészet közhelyeit értelmezi

megismétlő soroknak „Miért ugy futottál mint egy vad előttem? / A te halálod talán volt az én vétkem” (19. versszak) talán nincs valóságvonatkozása, vagy ha mégis van, valószínűleg nem a házasságtörő asszony halálba küldése miatt érzett lelkiismeret-furdalást fejezik ki. Draskovics Mária Eusébia halálának okát nem jegyezték fel. A kora újkorban a fogamzásra alkalmas korú nők közül sokan szülés közben vagy gyermekágyban haltak meg. Bethlen Miklós önéletírásában elmondja, édesanyját elhalt magzata ölte meg. (Bethlen 1980: 566). Az abortívum ilyen esetekben is tiltott eszköznek számított. A vallási elöírások nem mentesíthettek a felelősség alól, hiszen a vérmérgezést és a halált elöre lehetett látni.

11 Poliziano művében Orpheusz az Alvilág szörnyeit megbabonázza és a Halált is zokogásra indítja lantjátékával. (Poliziano, 2003: 112, 114)

12 Lásd: a Balassa-kódex Marullus versét parafrazáló, Kiben annak adja okát, hogyél, noha a lélek szerelmeséhez elszökött tüle címủ tizenhetedik költeményét. (Balassi, Tizenhetedik). Az első Idilium alábbi sorai az Orpheusz-költemény képeinek elemeit az Ariánna sírásának szél képével vegítik: „Nálad van én lelkem, hid, meg nem chalhatlak / Czak annyi lélek van bennem hogy ohajtlak / Holtnak én magamat, téged lángnak tartlak / Láng égben el röpül / itt holtak maradnak.// De te ohajtásommal könnyebben röpülsz, / ez a holt test nem mehet oda az hol ülsz" (Idilium I. 46, 47: 1-3).

13 A Balassa-kódex negyvennegyedik, A Darvaknak szól címú darabjának lírai énje a szálldogáló darvak egyikéről feltételezi: „Örömem környékét, az ő lakóhelyét: / paradicsomot látod”. (Balassi, Negyvennegyedik. Inventio poetica: grues alloquitur. A darvaknak szól. 4: 5-6). A negyvehetedik., Idövel paloták... incipitü, Angerianus költeményén alapuló versszerző találmány beszélöje pedig a következőket állítja: „Istentül mindenben adatott idővel / változás s bizonyos vég / Csak én szerelmemnek, mint pokol tüzének / nincs vége, mert égten ég." (Balassi, Item inventio poetica: az ö szerelmének örök és maradandó voltáról. 4: 5-6). 
át. A petrarkista szerelmes azért érzi úgy, hogy szerelme a pokol tüzéhez hasonló, mert viszonzatlanul maradó szenvedélye örök. Zrínyi költeményében azonban az teszi pokollá a szerelem állapotát, hogy a szenvedély a kedves halála után is változatlan marad.

A dispositio segítségével végrehajtott tudatos mítoszkorrekciónak kell tartanunk, hogy a párvers argumentuma a mítosz végét is elbeszéli, az ez után következő vers azonban az Alvilág ura előtt Eurüdiké kiadatása érdekében elmondott könyörgésre szorítkozik.

A történet módosításai segítségével olyan versén formálódik meg, aki bármiféle morális belátás nélkül a számára legfontosabb afektussal, a szerelemmel határozza meg önmagát. Az imitációs utalások is ezt támasztják alá. Az Orpheusz-mítosz legtöbbször hivatkozott két antik átirata Ovidius Átváltozások címủ munkájában és Vergilius Georgicájában található. Azt a pillanatot, amikor Orpheusz hátranéz, a Georgica szövege (a tankölteménynek ezen a pontján éppen a lekötözött Próteus beszél) így kommentálja:

... cum subita incautum dementia cepit amantem, / ignoscenda quidem, scirent si ignoscere Manes. (Georg. Lib IV: 487-488)

... fenn járt már, amidőn szerető szive hirtelen eltelt / őrült, óh, de bocsátandó vággyal - ha bocsánat / holtaknál van ugyan - ... (Georg. IV: 487-488, Lakatos István fordítása)

Zrínyi versének az alvilágba leszállni készülő beszélöje Dis urát és saját vállalkozását - a Georgicát megidézve - a következőképp jellemzi: „,...talán van kegyelem / abban, kegyelmesség, ki nem tud, mi légyen”. (Orpheusz I. 24: 3-4) $\mathrm{Az}$ azonos mondatszerkezet okán a versben az alvilági fejedelem feltételezett kegyelme mögött áttűnik a könyörületet érdemlő vétek, a mértéktelen szerelem. A versén az Alvilág ura előtt a következőt jelenti ki: „Az szerelem hozott, / Mert gyöplün hordozot" (Orpheusz II. 3: 4-5).

A két költemény annak a szenvedélynek a megoldhatatlan feszültségét artikulálja, melyet félbeszakított a halál. A kibontakozó, mértéket nem ismerő szerelem morális értelemben talán vétségnek tekinthető, a morális ítéletalkotáshoz azonban legalábbis arra volna szükség, hogy a versbeli beszélőt kívülröl lássuk, szavait a mitológiai hős szólamának tekintsük, - a költeményből azonban hiányzik a külső nézőpont.

Zrínyi Miklós a Syrena-kódex margójára odaírta a következő mondatot: Istud opus sine studio feci, nec dignum apparet, a készület nélküliség valószínüleg nem a dispositióra, hanem feltehetően a vers kidolgozottságának fokára, a korban nem sokra becsült önállóságára, az imitációs utalások viszonylag csekély voltára vonatkozik, ami talán a morális ítélatalkotás hiányát is felöleli.

A versén Orpheusszal azonosulva nem csupán a mitológiai hős beszédének fikcióját alkotja meg: Orpheusz szerepében személyes gyászáról vall. Mind a kortárs, mind pedig az egykorú befogadás konvencióit ismerő mai olvasótól annak megértése kíván erőfeszítést, hogy a két költeményben nem Orpheusz, a mitológiai hős monológját hallja, hanem a lírai én nyilvánul meg Orpheusz álarcában. 
Úgy tűnik, Zrínyi Orpheusz álarcát azért választotta, mert segítségével a keresztény kontextus érintése nélkül vallhatott gyászáról. Megkerülhette azokat a gondolati pályákat, amelyek a halott siratásakor kötelezők voltak: az Isten akaratába való belenyugvás, az ember bünösségének, a lélek túlvilági életének tárgyköreit. Ugyanakkor mélységesen kérdéses, hogy a 17. században radikálisan elfordulhatott-e a keresztény antropológia tanításától.

Eurüdiké halála a versben, az ókori mitológiát felülíró módon, a pogány főisten hatáskörébe tartozik. Orpheusz a feleségéröl a 3. versszakban megállapítja: „Ezt el-vitte az irigy s' kegyetlen halál" (Orpheusz I. 3: 3), a negyedik strófában pedig Eurüdiké haláláért Jupitert vonja felelősségre: „De te büneimért ha verni akartál, / Miért kegyetlenségben igy el-fajzottál / Jupiter, s' inkább én rám nem haragudtál, / s-haragos mennyküveddel el nem rontottál?’'(Orpheusz I. 4) Ezen a helyen, önmagát pogány hősökhöz (Enceladushoz és Prométheuszhoz) hasonlítva az kérdezi Jupitertől, vele miért nem bánt hasonlóan (Orpheusz I. 5). A beszélő önfelfogásában azonban Jupiter nem a halál metafizikai ura. Pogány mitológiai szerepének megfelelően Orpheusz később is azt kéri, a kegyetlen Fátum, Gorgonis, Busiris, az Ampopofrágusok, Scilla, Caribdis, a Furiák, a Hárpiák és a kegyetlen Párkák öljék meg (Orpheusz I. 16-18).

A keresztény képzetkörnek a pogányon való különös áttűnését Orpheusz maszkjának felöltése teszi lehetővé. Zrínyi a szerelem identitásképző hatalmáról Orpheusz álarcában nem morális szempontból, nem a rá váró életfeladat távlatából, hanem az emberi élet vége fölött is hatalommal rendelkező transzcendencia felöl formál ítéletet. A transzcendenciának a szenvedély felől nézve mélységes ellentmondását úgy fejezi ki, hogy elkerüli a szkeptikus álláspontot, és nem követ el szentségtörést sem, noha mindkettő közelébe kerül.

\section{Epigrammák}

Az Orpheusz-verseket követően a szerelmi költészet szólama többé nem hangzik fel a kötetben. Szörényi szerint az epigrammák beszélői, Attila, Buda és a szigetvári hősök az alvilágban bukkannak a szerző elé (Szörényi, 2004: 307). Annál, hogy valóságosan megképződik-e a pokol színpada, s a költő Krisztusként felhozza-e őseit az örök kárhozatból, fontosabb, hogy a megszólaló hősök eggyé váltak sorsukkal, érvényes hősi identitáspéldákká váltak, s ezt a sírfelirat müfajhagyományának megfelelően egyes szám első személyben ki is fejezik. A magyarok első királya, Attila és öccse, Buda, majd a szigeti várvédők szólalnak meg, az utóbbiak a dicsőség-hierarchia sorrendjében. Az utoljára szóló vitézek is, például az ostrom harmadik napján meghalt Farkasics Péter, akiknek kevésbé dicső végzet jutott, megemlítik, hogy a hős fiának (unokájának) éneke részesíti öket a dicsőségben (Radivoi és Iuranich Vajdák. 3: 2-3. Farkasich Péter, 2:2). 


\section{A himnusz}

A Feszületre mintájának, Girolamo Preti Invita l' Anima sua a piangere la Morte di Cristo címü versének (Bene, 2015b: 48) énje, az istenes költészet hagyománya értelmében, a lelkét hívja fel, hogy Krisztus halálát sirassa. Zrínyi himnuszának első versszakában a lírai én az édes Múzsát, addigi szerelmi költészetének ihletőjét aposztrophálja: nem a szerelmet, hanem a babérkoszorúval, a rothadandó füvel jellemzett szerelmi költészetet és a vele kiérdemelhető múlandó hírnevet ítéli el. Ez azonban azt is jelenti, hogy az istenes ének beszédét is költészetnek, s nem a könyörgés valóságának tételezte. A Múzsa az a lélekrész, akit figyelmeztetni kell létbeli helyére, megváltásra szoruló mivoltára („Hid-ki most magadbul könyvedet nagy okért / Arrasz cataractát szemedbül meltoért / Azért ki körösztfán függöt büneidért / Az ki Istened volt, meg-holt vátságodért." Feszületre. 2). A versnek nem a személyes büneit megbánó, a saját üdvözülésének ügye miatt aggódó szubjektum áll a középpontjában, hanem az eredendő bün terhét örökségként megkapó emberek közössége.

A versén, aki a Múzsa megszólítása után következetesen többes szám egyesben beszél, afelé fordul, ami elrejtetlenségében mintát és formát adhat az emberi önazonosságnak. A megváltó tett szemtanújaként Krisztust teremtőként szólítja meg, haláláért fejezi ki bünbánatát. Az ötödik versszakban múlt idejű igék jelzik a szenvedéstörténet kimenetelét: „Bajt-vittál, harczoltál halállal vitézül” (Feszületre 5:4), majd a lírai én a versbeszéd pillanatában is keresztfán függő (még élő vagy már holt?) vitézek Istenétől kérdezi meg: „Ki győzedelmes vagy, s’ ezer sereged van, / Hun karod, fegyvered, hun vitézséged van / Hun van Angyali Kar, hun Istenséged van?” (6: 2-4). A hetedik versszakban választ ad: „Hei, mert te ezeket mind fottig le-tetted, / Egy hatalmadat nagy Istenségedet / Az Emberi tested magadra fölvetted, / Azért hogy hullathasd érettünk véredet." (Feszületre. 7) A 8. versszakban a beszélö összefoglalja a megváltás- és szenvedéstörténet legfontosabb tényeit, majd a következő szavakkal fordul a Krisztus és az Atya személyét egyaránt magában foglaló Istenhez: „O te nagy Jehova kegyelem forrása, / Kegyelmes Eloim nagy Istennek fia / Seregek Istene Sidoknak királlya, Alfa és Omega és jók bizodalma!” (Feszületre. 9) a kegyelmét kéri, irgalmának nagyságával érvel.

Krisztus kereszthalála Istennek az emberiség felé forduló gesztusa. Az emberré vált Istennek maradéktalanul osztályrésze a halál. A mártír Krisztus példáját követi, ám a Krisztus-követés nem a példa puszta megismétlése, hanem Isten felé fordulás is: az önkéntes halál vállalásához annak hitére van szükség, hogy a személyes megsemmisülés Isten szeretetére ad választ. A hősi tett a halál segítségével megformált identitás, az önkifejezés gesztusa. A hős nem egyszerüen alter Christusszá változik, hanem önmaga azonosságát úgy fejezi ki, hogy az ügyet élteti önmaga helyett. A dédapa a szabadság és az önmegőrzés utolsó, paradox gesztusát hajtja végre. Halálával pecsételi meg a létét. A himnusz ezek szerint az identitás- és sorsminta vállalásának hitbeli feltételét fejezi ki. 
A hirnév és a halál

A Peroratio zárómetaforája a minden konnotatív jelentést ${ }^{14}$ nélkülöző testi megsemmisülés képe:

De hiremet nem chak keresem pennammal,

Hanem rettenetes bai-vivo szablyammal;

Míg élek hartzolok az ottoman hoddal,

Vigan burittatom hazám hamviaval.

(Peroratio 4)

A Peroratio a majdani, valóságos tettet nem helyezi a költészet fölé. A név elveszik a testi halállal, legalábbis arra a fölmérhetetlen pillanatra semmivé lesz, amíg a név folytonosságát a tettet megörökítő mủ helyre nem állítja. A Syrenakötet ezen a ponton ér véget, sem a majdani hőstett, sem pedig megéneklése nem tárgya.

A kis Izsákot sirató költeménye tanúsága szerint a „tett” és a „megéneklés” a nemzedékek ritmusában váltja egymást, az apa hőstettét a fiú énekli meg, miközben maga is méltóvá válik arra, hogy cselekedetét egykor megörökítsék:

Igy számlálom vala az én jövendőmet,

Hogy sok üdő mulván ez megvált engemet,

Hogy követi, meg is haladja versemet,

És szegény hazánkért igyekezetemet.

S zengőbb trombitával magyar vitézséget,

Fogja énekleni erős kar erejét.

És hogy ü is osztán érdemeljen illyet,

Kinek énekelhessék cselekedetét.

([Elégia]. 12-13)

A hősepikában a fiú hősiességben valóban apja nyomdokába lép, ám az apa cselekedetének megörökítése nem a fiú feladata, Zrínyi a saját példáját teszi általános érvényűvé.

\section{Összegzés}

Előszavában Zrínyi egymás mellé helyezi, egymáshoz illőnek mondja a szerelmet és a vitézséget. Ennek megfelelően a kötetben párhuzamosan bontja ki a szerelmi költészet és az eposz szólamát. Erotikus verseiben a szerelmet

\footnotetext{
14 Bene Sándor a Peroratio záróképét összefüggésbe állítja az Ariánna sírásának záradékával: „A „Vigan burittatom hazám hamujával" zárósor pedig az önáldozat helyes módjára mutat rá az Arianna befejezéséhez képest: ott a szenvedély/szenvedés könnyárja »burít«, azaz öl, itt az érzelmi Én-s vele a költészettemettetik. [...] A költészet elhagyása beépül a költői üzenetbe, ha úgy tetszik, ez-az erős, Zrínyi szótárában »nagyszívü«, magnanimus - egyéniség lesz a kötet »alapeszméje«.” (Bene, 2015a: 49).
} 
kiszabadítja a petrarkista lírára jellemző öreflexív énformálás kötelékéből. A szerelem a könyvben nem morális szempontból ítéltetik el: a szenvedély a halál fölött is uralkodó transzcendencia felfoghatatlan hatalma következtében bizonyul elégtelennek az emberi identitás megalapozásához. A himnusz beszélője szeretetként ismeri föl a transzcendenciát, a szigeti várvédő mártírhalálát pedig az egyedül érvényes identitáspéldaként mutatja föl.

\section{FORRÁSOK}

Balassi, Bálint. Összes költeményei. http.//mek.oszk.hu/00600/00609/0069.htm Bethlen, Miklós (1980). Bethlen Miklós élete leírása magától. In: Kemény János és Bethlen Miklós müvei (399-982). Bp.: Szépirodalmi Könykiadó.

P. Vergilius, Maro (1829). Bucolica et Georgica. Martyn, John F.R.S. Oxford: Vincent, J.

P. Vergilius, Maro. Georgica. In: Vergilius összes müvei. Lakatos, István (ford.) http:// mek.oszk.hu/06500/06540/06540.htm

Zrínyi, Miklós ( 1980). Adriai tengernek Syreneaia (1651). Kovács Sándor Iván (utószó). Bécs: Cosmerovius. Hasonmás kiadás.

Zrínyi, Miklós. [Elégia]. In: Zrínyi Miklós összes költeménye. http://mek.niif. hu/01100/01137/01137.htm

Henkel, Arthur, Schöne, Albrecht (hrsg.) (1996). Emblemata: Handbuch zur Sinnbildkunst des XVI. und XVII. Jahrhunderts (2., Taschenauflage). Stuttgart. Weimar: J.B. Metzler.

\section{IRODALOM}

Bene, Sándor (2014). A vadász és Viola. Zrínyi Miklós első házassága. Irodalmi Magazin, 4: $40-43$.

Bene, Sándor (2014a). A költöi művek keletkezésének időrendje. Irodalmi Magazin, 4: 44-46. Bene, Sándor (2014b). Adriai tengernek Syreneaia Groff Zrini Miklos - a kötetkompozíció. Irodalmi Magazin, 4: 47-50.

Bene, Sándor (2014c). Júlia - avagy az „első vers” legendája. Irodalmi Magazin, 4:55-58.

Brajović, Saša (2009). Renesansno sopstvo i portret. Beograd: Filozofski fakultet. Univerzitet u Beogradu.

Király, Erzsébet (1989). Tasso és Zrinyi. A „Szigeti veszedelem” olasz epikai modelljei. Bp.: Akadémiai Kiadó (Humanizmus és Reformáció, 16)

Kiss Farkas, Gábor (2006). Képalkotás és imagináció a Szigeti veszedelem címlapján. In: $O$ szelence. Magyar barokk költészet (88-107). Orlovszky, Géza. Szilasi, László (szerk). gepeskonyv.btk.elte.hu/adatok/Magyar/55 Orlovszy/tan/cimlap.pdf

Klaniczay, Tibor (1964). Zrínyi Miklós. Bp.: Akadémiai Kiadó.

Kovács, Sándor Iván (1980), Utószó az Adriai tengernek Syrenaia hasonmás kiadásához, Bp.: Akadémiai Kiadó (Magyar Helikon). 1-79.

Kovács, Sándor Iván (1985). A lírikus Zrínyi. Bp.: Szépirodalmi Kiadó.

Kőszeghy, Péter (2014). Magyar Amphión. Bp.: Balassi Kiadó.

Krems, Eva-Bettina (2009). Das Drama des Sehens und der Musik. Zur Darstellung des Orpheus-Mythos in bildender Kunst und Oper der Frühen Neuzeit. Marburger Jahrbuch für Kunstwissenschaft 36: 269-300. 
Nelting, David (2007). Frühneuzeitliche Pluralisierung im Spiegel italienischer Bukolik. Tübingen: Günter Narr Verlag (Romanica Monacensia, 74).

Müller, Jan-Dirk, Oesterreicher, Wulf, Vollhardt, Friedrich (Hrsg.) (2010). Pluralisierungen. Konzepte zur Erfassung der Frühen Neuzeit. Berlin, New York: De Gruyter (Pluralisierung \& Autorität, 21).

Ricoeur, Paul. André, LaCocque (2003). Bibliai gondolkodás. Ford. Enyedi, Jenő. Bp.: Európa Kiadó

Szörényi, László (2004). Zrínyi és Vida, avagy a neolatin vergiliusi eposzmodell. In: Religió, retorika, nemzettudat régi irodalmunkban (297-315). Bitskey, István, Görömbei András (szerk.). Debrecen: Kossuth Egyetemi Kiadó (Csokonai Könyvtár, Bibliotheca Studiorum Litterarium, 31).

Szörényi, László (2007). A szerkesztett versekötet mint a szerzö ifjúkori önarcképe. In: $A$ magyar irodalom történetei a kezdetektől 1800-ig (467-486) Szegedy- Maszák Mihály (szerk.) Bp.: Gondolat. 
Čila Utaši

\title{
ODNOS LIRSKIH PESAMA I EPA U KOMPOZICIJI ZBIRKE „SYRENA” NIKOLE ZRINSKOG
}

\begin{abstract}
REZIME
Nikola Zrinski u svojoj zbirci pod naslovom Adriai tengernek Syreneaia: groff Zrini Miklos (Jadranskog mora Sirena: grof Nikola Zrinski) objavljenoj u Beču 1651. godine, bukoličke pesme je rasporedio oko epa, dok je epigrame o mađarskim kraljevima i junacima Sigeta postavio na kraj svog dela, kao i himnu pod naslovom Feszületre (Ka raspeću) i Peroratio. Prema Laslu Serenjiju (Szörényi László), u kompoziciji zbirke se takmiče pastoralni, erotski i elegijski pesnički univerzumi sa herojskim. Himna presuđuje o ishodu borbe žanrova, prvenstvo daje herojskom glasu, međutim, u zaključnoj pesmi i sâm herojski glas biva proglašen ništavnim u poređenju sa stvarnom herojskom smrću. Šandor Bene (Bene Sándor) u strukturi zbirke rekonstruiše priču o moralnom pročišćenju jedne duše i smatra da ovaj proces predstavlja težište same zbirke. Oba istraživača centralnu važnost pridaju pesmama o Orfeju. U ovim pesmama Nikola Zrinski oplakuje svoju prvu suprugu, Mariju Euzebiju Drašković. Prema autorki studije, lirsko ja u ovim pesmama ne odriče se ljubavi, već upravo obrnuto, samog sebe određuje svojom beskrajnom strašću. Stihovi o Orfeju artikulišu nerešivu napetost ljubavi: zbog postojanja smrti, ljubav nije dovoljna da bi se na njoj mogao utemeljiti ljudski identitet. Govornik himne se obraća razapetom Hristu, a u činu spasenja prepoznaje primer i oblik ljudskog identiteta. Prema zaključku ove studije, lirske pesme zbirke imaju za zadatak da potvrde kao jedino autentičan onaj obrazac ljudskog identiteta koji je oblikovan u epu.
\end{abstract}

Ključne reči: Nikola Zrinski, zbirka „Syrena”, takmičenje pesničkih žanrova, Orfej, priča o moralnom pročišćenju, himna, paradigma identiteta. 
Csilla Utasi

\section{THE CONNECTION BETWEEN THE LYRICAL POEMS AND THE EPIC IN STRUCTURE OF MIKLÓS ZRÍNYI'S SYRENA-VOLUME}

In Miklós Zrínyi's volume under the title of The Siren of the Adriatic Sea: count Miklós Zrini (Adriai tengernek Syreneaia: groff Zrini Miklos), which was published in Vienna in 1651, bucolic poems precede the epic, imitating and encompassing it. The collection closes with royal and heroic epigrams, as well as the hymn entitled To the Crucifix (Feszületre) and Epilogue to the Zrinyiad (Peroratio). The issues concerning the structure of the volume came into the limelight during the previous decade. According to László Szörényi, the organizing principle of the Hungarian Siren volume is the struggle of bucolic, erotic and elegiac poetic worlds on the one hand with the heroic one on the other. Szörényi is of the opinion that the hymn decides the competition of the poetic genres in favour of the heroic one, whereas the heroic voice is regarded worthless in comparison with the heroic death. Sándor Bene reconstructs the narrative of a soul in the Syrenavolume, concluding that the moral history of purification evolving from the short poems becomes more important than the epic. All the critics who have tried to explain the poem place the turning point of the volume on the part containing the Orpheus poems, the epigrams and the hymn. The Orpheuspoems lament the death of Miklós Zrínyi’s first wife, Mária Eusébia Draskovics. According to the author of the essay, the lyrical subject of these poems does not become estranged from passion, quite the contrary, it identifies with excessive passion. Due to the sheer fact of death, in the Orpheus-poems, love is not enough to justify the human identity. The speaker of the hymn addressing the crucified Christ recognises God's redeeming gesture, the deed serving as a model to the human existence. The paper ends with the conclusion that the function of the lyrical poems in the volume is to present the paradigm of identity offered by the epic as authentic.

Keywords: Miklós Zrínyi, Syrena-volume, contest of poetic genres, moral history of purification, Orpheus, hymn, paradigm of identity. 